\title{
The Language of Gesture.
}

\section{H. A. Rose}

To cite this article: H. A. Rose (1919) The Language of Gesture., Folklore, 30:4, 312-315, DOI: 10.1080/0015587X.1919.9719112

To link to this article: http://dx.doi.org/10.1080/0015587X.1919.9719112

$$
\text { 曲 Published online: } 01 \text { Feb } 2012 .
$$

Submit your article to this journal $₫$

Џll Article views: 2

Q View related articles ¿ 


\section{The Language of Gesture.}

DR. J. P. VOGEL has recently contributed to the Verslagen en Mededeelingen der Koninklijke Akademie van Wetenschappen, Afd. Letterkunde, 5e Reeks, Diet iv.,' a valuable note (in English) on the Sign of the Spread Hand or "Five-finger token " (Pancangulika) in Pali Literature. This sign seems to have originated in gesture, and though few races are so dependent on that mode of expression as not to be able to converse without it, like the Bubis of West Africa who cannot talk in the dark, as among them "language depends so much on gesture," " few races exist who use nothing but the tongue to communicate ideas. Gesture, elaborately conventionalised, plays a great part in Indian iconography. ${ }^{3}$

And such conventions must be of great antiquity, as is gesture $i$ 'self. In a curious pa sage of the Jatakas ' the Great Being meets the lady Amara and thought, "Whether she be wed or not I do not know: I will ask her by hand gesture, and if she be wise she will understand." So standing afar off he clenched hi: fist. She understood that he was asking whether she had a husband, and spread out her hand-to signify that she was married. It would appear then that the original meaning of the open hand was freedom or liberty. But in Persia the clenched hand denote, besides austerity or violence, close-fistedness, just as the spread hand signifies open handedness. ${ }^{5}$

The spread hand. however, may express a very different entiment in modern India, where gesture is still much used. Thus, in the Western Punjab, at least in two districts ot it, some of the gestures are peculiar, although, as in Europe a nod of the head means "yes," or "come," and a shake "denizl." A backward nod means inquiry, a click with a toss of the head means "no," jerking the fingers means "I do not know";

'Available in an off-print. Amsterdnm : J. Maller, 1919.

- Mary Kingsley, Travels in Wast Africa, p. 439.

"The Bronses of Southern India, O. G. Gangoly, 1915.

Jataka, Cowell and Rouse, vi. p. 182.

- North Indian Notes and Queries, i, 42. 
holding the palm inwards and shaking the head is a sign of prohibition, holding up the thumb means contemptuous refusal, wagging the middle finger provokes a person to anger, and holding up the open palm is a great insult. Why this last gesture should be insulting doe; not appear. 1 The tracts in question are peopled by dominant Muhammadan tribes, and the open hand is common on the standards of their Afghan co. religionists across the north-west frontier. In beckoning the hand is held up, palm outwards and the fingers moved downwards and inwards--just the reverse of our gesture. But these differences are readily explicable. The Indian's palm is always much lighter than the back of his hand, 'o the colour of the palm must attract the attention of the person whom he wishes to call to him much more than the less conspicuous complexion of the back would do. Then the extensor muscles being weaker in all Orientals than the flexor, a great many muscular opposites occur among them: notably in pulling instead of pushing a saw, and the like.

The middle-finger gesture seems to be an atrempt to represert a snake's tongue. In Indian art we find a very similar gesture styled the Suchi-hasta or "needle-pointed hand." " This term is so translated by Mr. Gangoly, but the resemblance to a needle is not very great. The middle-finger seems to be intended for the tongue as the two fingers on either side of it seem to repre. sent the hood of a cobra. Were putting out the tongue and hissing derived from a similar imitation of the poisonous snakes? Seeing that we find a Sinha-karna hasta or "tiger-making hand" and a gaja-hasta or "elephant's trunk" among the Indian mudras or finger-poses, just as we find children still making shadow-pictures of rabbits, etc., nn the wall with their hands, this conjecture seems justified. Other mudras are the half-

\footnotetext{
'See Iunjab District Gasetteer, Attock, 1907, p. 113 , quoting Sir lames Wilson's Shahpur Gazetteer. The local words for thumb, thuth, and middle finger, dhiri, may have sone significance. In sitting the two most usual postures have separate names: athrihha, "sitting on the heels," and palthalli, "squatting on the ground cross-legged."

"Bronses of Southern India, p. 45. It is also called Suchi-mukha hasta, which stggests that it is intended to represent a mouth and fangs. 
moon (ardha-chandra) and kartari-hasta, which seems to be an attempt to represent the Indian katär or dagger hidden by the arm. ${ }^{1}$ But it is quite possible that this pose, in which the index and little fingers are kept straight and the two middle ones lowered represents a deer as dancing-girls in Southern India still so represent that animal, curving the two upright fingers slightly backwards to indicate its horns."

'The diagrams given by $\mathrm{Mr}$. Gangoly appear to represent the fingers in motion as well as in repose. Thus the Sinha-karna hasta seems to represent the index finger closing in on the thumb (Diagrams $\mathrm{S}$ ), but in $\mathrm{X}$ it is the middle-finger which is so moving down. Similarly, the Kataka-hasta, from which Mr. Gangoly derives the Sinha-karna, appears to be always in quick movement. In fact, he speaks of the mudras as "actions of the finger." On the other hand all the open hands are apparently in repose, as in Diagrams D (Araya-hasta), and O (Arayamudra-Patzka-hasta). As when "all the fingers [are] spread out together, the thumb being curled up, it is known as pataka," there are doubtless other varieties of the Abhaya mudra, or re-assuring gesture, each with its shade of meaning. In the Abhaya the fingers are spread out: indeed, as a rule they are held close together but not all pressed together. ${ }^{3}$ The open palm used to express contempt has, probably, the fingers radiating from it and bent slightly backwards. The hand held out horizontally with the palm upwards and the fingers in disarray, as it were, signifies resignation or despair-a gesture which has survived in modern Europe."

${ }^{1}$ Jbid. p. 44. Mr. Gangoly does not translate the term, lut says it is identical with the Kartari-mutha. IIis dingram $\mathrm{M}$ is queried as a Kastarihasta, but it strongly suggests the side pieces of the katir.

2 The Arts and Crafts of Kndia and Ceylon, Ananda Coomaraswamy, 1913, pl. 9, p. $3 \mathbf{I}$.

- See, for instance, pl. 5 at p. $3 \mathrm{I}$ of Coomaraswamy, op. cit. In plates 3 and 4 he figures two distinct forms of the vitarka mudra, which are. I believe, still commonly used in India, though their precise significances are not known to me.

"See "With the Five Fingers," by Samarendranath Gupta, in Nodern Review, Calcutta, I913, vii. p. 169. 
While much in the gesture-language of India is still obscure, it seems to be clear enough that the so-called poses of Indian art include gestures as well as poses of the hands and that the conventionalised forms of both were based on a widely used, well understood and somewhat elaborate gesture-language.

H. A. Rose.

Prentice Pillars. Architect and his Pupils.

(Folk-Lore, vol. xxix. p. 219.)

THE following is a story current in the south of the Cochin State, Malabar. Near the Station of Alwaye on the Periar, there is a small village named Uliyannur. Long long ago there lived a master builder of the name Uliyannur Perumthachan. Many of his works are still extant to-day. One of them is the village temple at Uliyannur. The roof is so arranged over a flight of stairs that if you bend to avoid the low roof you are sure to hit your head on the rafters. But if you walk straight up you are unhurt.

Once they wanted him to build a tank, but each one wanted the bathing ghat to face a different direction. Finally, when he built it anyone used to lose his sense of direction the moment he got inside it. This tank was destroyed some years ago when the railway was built.

He is even reputed to have changed the course of a stream.

Once he built a bridge and set a doll at the head of it with the mechanism so arranged that it spat water at the face of anyone who set foot on the bridge. After a time his son himself--a gifted worker-came along and saw it. He built another doll and set it near the first. As soon as the father's doll spat water, the son's would give a slap on its face. When the father saw that the next day, he marvelled at it but thought, "If I let this boy of mine to grow up he will be greater than myself." $\mathrm{He}$ was engaged in building the roof of a house. He sent the boy down to fetch a tool. When he was bending to take the tool he let fall a chisel on him and thus killed him. 